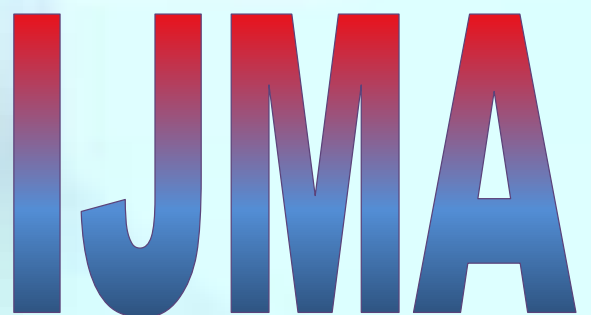

INTERNATIONAL

Journal of MEdical

\section{ARTS}

Volume 3, Issue 1 (Winter 2021)

http://ijma.journals.ekb.eg/

Print ISSN: 2636-4174

Online ISSN: 2682-3780

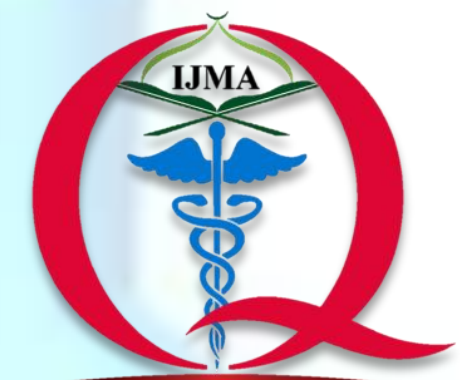

International Jounnal of Medical Arts

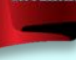




\section{About IJMA}

- International Journal of Medical Arts is the Official Journal of the Damietta Faculty of Medicine, Al-Azhar University, Egypt

- The First Issue was published in July 2019

- It is an International, Open Access, Double-blind, Peerreviewed Journal

- Published four times a year

- Published under the following license: Creative Commons Attribution-ShareAlike 4.0 International Public License (CC BY-SA 4.0). It had updated from the Creative Commons license [CC BY] in volume 2, Issue 4, October 2020

- The Egyptian Knowledge Bank hosts the web site of IJMA

- The Egyptian Knowledge Bank supports IJMA

- IJMA is indexed in the "Directory of Open Access Journals" Indexed on 15 January 2021.

- IJMA follows the regulations of the International Committee of Medical Journal Editors (list date 1/21/20)

- IJMA is a member of The International Society of Managing and Technical Editors

- IJMA is listed in Index Copernicus

- IJMA is listed in Publons, as EKB is an official partner with Clarivate Analytics
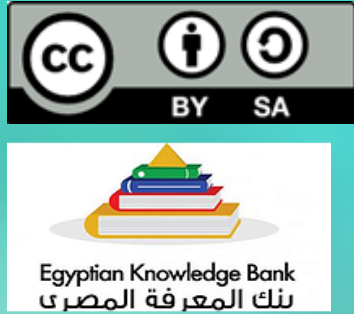

\section{DOAJ}

CMNE

ISMTE

INDEX COPERNICUS

publons 
International Journal of Medical Arts 2021; 3 [1]: 1088-1096.

Available online at Journal Website
https://ijma.journals.ekb.eg/
Main subject [Pediatrics]

Original article

\title{
Evaluation of Serum Insulin, Glucose and Liver Function in $\beta$-Thalassemia Major and Their Correlation with Iron Overload
}

\author{
Basma Mohammed Ahmed Matar ${ }^{[1]}$; Magdy Mohammed Ashmawy Sakr ${ }^{[1]}$; Lotfy Abd Elfattah Elsehaimy ${ }^{[1]}$; \\ Hesham Samir Abd El-Sameea ${ }^{[2]}$ \\ Department of Pediatrics, Damietta Faculty of Medicine, Al-Azhar University, Egypt[1] \\ Department of Clinical Pathology, Damietta Faculty of Medicine, Al-Azhar University, Egypt[2]
}

Corresponding author: Basma Mohamed Ahmed Matar

Email: basmamohammed305@gmail.com

Received at: September 22, 2020; Revised at: November 19, 2020; Accepted at: November 26, 2020

DOI: 10.21608/ijma.2020.43776.1179

\section{ABSTRACT}

Background: Beta-thalassemia syndromes are a set of hereditary blood disorders marked by a deficiency of betaglobin chain synthesis, resultant in decrease hemoglobin in red blood cells [RBC], anemia, and a reduced $\mathrm{RBC}$ production

Aim of the work: To evaluate glycometabolic and liver function in cases with $\beta$-thalassemia major and their correlation with serum iron and ferritin

Patients and methods: This was a case-control study that was performed in the pediatric department of Al-Azher University Hospital in Damietta from June 2018 to June 2019. Fasting serum glucose, insulin, and liver enzymes were assessed for 48 cases and 40 ordinary controls. Serum iron and ferritin were recorded as an indicator of iron overload

Results: Fasting serum insulin, alanine transaminase [ALT] levels, aspartate transaminase [AST] levels were significantly high in thalassemia major [TM] cases than in the control group [P<0.05 for all]. As showed, the serum iron and serum ferritin showed a highly significant increase in the patients' group more than the control group.

Conclusion: The kids with $\beta$-TM have a high glycemic disorders incidence rate, may be because of the insulin resistance due to the amplified iron burden.

Keywords: $\beta$ thalassemia major [TM]; Serum Insulin; Glucose; Iron Overload

This is an open-access article registered under the Creative Commons, ShareAlike 4.0 International license [CC BY-SA 4.0] [https://creativecommons.org/licenses/by-sa/4.0/legalcode.

Please cite this article: Matar BMA, Sakr MMA, Elsehaimy LA, Abd El-Sameea HS. Evaluation of Serum Insulin, Glucose and Liver Function in $\beta$-Thalassemia Major and Their Correlation with Iron Overload. IJMA 2021; 3[1]: 1088-1096. DOI: 10.21608/ijma.2020.43776.1179

\footnotetext{
${ }^{*}$ Main subject and any subcategories have been classified according to the research topic.
} 


\section{INTRODUCTION}

Thalassemias are a heterogeneous set of disorders of genes resultant from faults in genes production $a$ or $\beta$-globin chains. $\beta$-thalassemia comes from a fault in $\beta$-globulin chain making that gives various results varying from severe anemia to clinically asymptomatic persons. The worldwide incidence rate is valued at one per 100,000[1].

The disorder influences all genders but have a higher prevalence in certain ethnicities and age levels. It is the most frequent disorder in the blood genes all over the world and is fast growing. A $7 \%$ of the Global residents having this disorder, and 400,000 babies have come with the trait annually[2]. The beta form of thalassemia is particularly prevalent among the Mediterranean peoples, and this geographical association is responsible for its naming. Beta Thalassemia is the most common chronic hemolytic anemia in Egypt [85.1\%], with a carrier rate of approximately $10 \%[3]$.

Beta thalassemias are produced by an alteration in the gene of hemoglobin- $B$ on chromosome-11, inherited in an autosomal recessive manner. The severity degree of the disorder is based on the mutation properties. hemoglobin- $\beta$ blockage through time guides to reduced beta-chain synthesis. The body's failure to produce new $\beta$-chains guide to the underproduction of $\mathrm{HbA}[4]$.

Because of this feature, the cases might need a blood-transfusion to perform the blockage in the $\beta$-chains. Continual blood-transfusions may guide to the accumulation of iron, eventually resultant in an iron-toxicity. This iron-toxicity may lead to several complications, counting myocardial siderosis and heart failure, and finally, case mortality[1].

Children having this disorder need a steady lifetime blood-transfusion and may suffer from further complications. Cases obtain regular bloodtransfusions that guide to or potentiate iron excess. A treatment of Iron chelation is required to avoid interior organs damaging.

The therapy involves a regular bloodtransfusion, splenectomy if hypersplenism is existing, and treating of transfusion-lead to iron excess. Because of new improvements in iron chelation therapy, cases with thalassemia major to have a lifetime with admission to suitable treatment. Common chelators including deferoxamine and deferiprone ${ }^{[5]}$.

Amplified gastrointestinal iron absorbance is detected in all levels of $\beta$-thalassemia and raised RBC annihilation by the spleen because of unsuccessful erythropoiesis supplementary produces extra iron into the blood-stream[6].

Cumulation of iron leads to a big health problem for the heart, liver, and endocrine glands. Severe symptoms involving cirrhosis and fibrosis for the liver and in dangerous patients lead to liver cancer: heart failure, diabetes, growth weakening, and osteoporosis ${ }^{[7]}$.

Advanced intolerance in glucose or Diabetes Miletus [DM] is the chief metabolic problem in a high percentage of cases with $\beta$-thalassemia major and share to general morbidity. But, the pathogenetical mechanisms guide to DM are not completely explained, and many authors now trust that iron admission in the pancreatic $\beta$-cells is the main reason $[8]$.

This suggestion is validated by the improved incidence rate of DM detected in idiopathic hemochromatosis and in post-transfusional iron excess. This conclusion is not depending on the glucose tolerance grade and frequently is straightly linked with serum biomarkers of long-time irontoxicity like serum ferritin, serum aspartate aminotransferase, liver iron, and the period of the blood transfusion therapy[9].

Furthermore, liver complaints and genetic effects appear to be different predisposing influences. In specific insulin resistance, because of liver harm, has been requested to use a pivotal function in the complication progress ${ }^{[10]}$.

\section{AIM OF THE WORK}

This work was performed to evaluate glycolmetabolic and liver-function in cases with $\beta$ thalassemia major and their association with serum iron and ferritin.

\section{PATIENTS AND METHODS}

After obtaining approval from the ethics committee, this study was a case-control one that was performed in the pediatric department of Al- 
Azher University Hospital in Damietta over an interval of one year [from June 2018 to June 2019]. This work involved 48 cases with the $\beta$-thalassemia major with a mean aging of 6-18 years receiving periodic blood-transfusions. An extra 40 normal persons matching the same age range were included as controls.

The thesis was accepted by the Faculty of Medicine's ethical review committee at Al Azhar University. The work was carried out for human studies in agreement with the World Medical Association's Code of Ethics [Helsinki Declaration].

Inclusion criteria: $\beta$ thalassemia major patients receiving blood transfusion; and both sexes were included.

Exclusion criteria: Inborn error of metabolism; diabetes mellitus; chronic infection [as chronic hepatitis, TB], and Chronic liver disease.

All studied patients were exposed to medical history taking, clinical examining, and abdominal, cardiovascular, and neurological examination.

Thalassemia children who came for blood transfusion were asked to come on an empty stomach for 8 hours next time. On the next visit, blood was obtained for serum assessment of glucose, insulin, liver enzymes, iron, and ferritin

Fasting serum glucose, insulin, and liver enzymes [AST and ALT] were measured for both the cases and normal control. Serum iron and ferritin were determined as a marker for iron excess. Fasting serum glucose, serum glutamic-pyruvic transaminase [SGPT], serum glutamic-oxaloacetic transaminase [SGOT], and serum iron have been done by an automated chemistry analyzer [B.T.1500 Biotecnica, Italy]. Ferritin and serum insulin was done via Enzyme-linked immunosorbent assay [ELISA] [Tecan, Swizerland] in accordance with manufacturers' instructions.

Fasting Serum glucose level [normal value for age 6-12 was $70-120 \mathrm{mg} / \mathrm{dll}]^{[11]}$. Fasting serum insulin level [normal value for age 6-12 was 5.0-34.0 $\mu \mathrm{IU} / \mathrm{L}$ ] ${ }^{[12]}$. Liver enzymes [ALT, AST] [ALT normal value was 5-35 U/L; AST 15-40] [13]. Total serum iron and serum ferritin [normal value was of serum iron was $5-27 \mu \mathrm{mol} / \mathrm{L}$ and serum ferritin was 18-81 $\mu \mathrm{g} / \mathrm{L}]$.
Statistical Analysis: Statistical analyses were carried out using IBM-SPSS version 20 software. Qualitative information was introduced in the form of numbers and percents. A matching among various groups for definite variables was performed via the Chi-square test. Quantitative data was introduced in the form of mean and standard deviation [SD] for ordinarily distributed data, whereas unusually distributed data was introduced in the form of the median, minimum, and max. For ordinarily distributed data, a comparing among two separated groups was demonstrated via an independing t-test. P-value of $<0.05$ was counted as statistically significant.

\section{RESULTS}

Table [1] presented a comparison among the groups included in the current work as regards demographic data, the sex in the two was comparable, regarding age no significant change among the two groups existed [P>0.05], the patients ages was $12.54 \pm 3.60$ years while for the controls was $12.10 \pm 0.92$ years. Regarding the residence, no significant change among the studied groups was detected.

The matching among the groups of the study with regard to anthropometric measurements, the height, and weight in controls was significantly high in comparison with the group of cases $[p<0.05]$.

Also, regarding vital signs, the pulse in patients was $106.42 \pm 11.04$, while in the control group, it was $96.68 \pm 10.37$, and a significant rise in pulse in patients in comparison with the control group [p < $0.05]$ was exist. The temperature in the two groups was around $37^{\circ} \mathrm{C}$, and there was no significant change among the studied groups concerning temperature [p.>0.05].

Table [2] showed the matching among the groups of the study concerning serum glucose and serum insulin level, the mean serum glucose in patients was $87.4 \pm 12.78$, while in the control group was $89.5 \pm 11.26$, there was no significant change among the groups under investigation concerning serum glucose, the serum insulin in patients group was $13.7 \pm 13.13$, while in the control group was 8.15 \pm 2.49 , there was a significant rise in serum insulin for cases more than the control group $[p<0.05]$. 
The comparing among the groups of the study concerning serum iron and serum ferritin level, the mean serum iron in patients was $262.1 \pm 75.48$, while in control was $36.15 \pm 15.16$, the serum ferritin in patients was $2626.79 \pm 690.17$, while in control was $25.93 \pm 18.24$, there was a highly significant increase in serum iron and serum ferritin in patients more than the control. Table [3] showed the matching among the groups of the study concerning liver function test, the SGPT in the patients and control was matched without significant difference. In contrast, the SGOT shows a slightly significant increase in patients more than the control $[p<0.05]$. Table [4] showed the correlation between serum iron and serum ferritin in relation to liver function test [SGPT, SGOT]; it was found that there was no significant correlation between both SGPT and SGOT regarding serum glucose and insulin [ $p>0.05]$.

Figure [1] showed the correlation between serum iron and serum ferritin in relation to age, age of onset, frequency of transfusion/year, and the dose of iron-chelating agent/day; it was found that a significant positive association existed among both serum iron in relation to the frequency of transfusion/year and the dose of iron-chelating agent/day, and negative correlation between serum ferritin and both to the frequency of transfusion/year and the dose of iron-chelating agent/day. While the age, age of onset, and duration of the disease show insignificant relation with both serum iron and ferritin.

Table [1]: Comparison between studied groups as regards Demographic data and regarding vital signs

\begin{tabular}{|c|c|c|c|c|c|c|c|}
\hline & & \multicolumn{2}{|c|}{$\begin{array}{c}\text { Patients group } \\
n=48\end{array}$} & \multicolumn{2}{|c|}{$\begin{array}{c}\text { Control group } \\
n=40\end{array}$} & \multirow[t]{2}{*}{ test } & \multirow[t]{2}{*}{$P$ value } \\
\hline & & No. & $\%$ & No. & $\%$ & & \\
\hline Sex & $\begin{array}{l}\text { Male } \\
\text { Female }\end{array}$ & $\begin{array}{l}25 \\
23\end{array}$ & $\begin{array}{l}52.08 \\
47.92\end{array}$ & $\begin{array}{l}24 \\
16\end{array}$ & $\begin{array}{l}60.0 \\
40.0\end{array}$ & $X^{2}=0.93$ & 0.231 \\
\hline Age [year] & $\begin{array}{l}\text { Range } \\
\text { Mean } \pm S D\end{array}$ & \multicolumn{2}{|c|}{$\begin{array}{c}6-18 \\
12.54 \pm 3.60\end{array}$} & \multicolumn{2}{|c|}{$\begin{array}{c}6-18 \\
12.10 \pm 3.92\end{array}$} & $t=0.72$ & 0.292 \\
\hline Residence & $\begin{array}{l}\text { Rural } \\
\text { Urban }\end{array}$ & $\begin{array}{l}26 \\
22\end{array}$ & $\begin{array}{l}54.17 \\
45.83\end{array}$ & $\begin{array}{l}17 \\
23\end{array}$ & $\begin{array}{l}42.5 \\
57.5\end{array}$ & $X^{2}=1.65$ & 0.140 \\
\hline Height [cm] & $\begin{array}{l}<3^{\text {rd }} \text { percentile } \\
>95 \text { percentile }\end{array}$ & $\begin{array}{l}19 \\
29\end{array}$ & $\begin{array}{l}39.6 \\
60.4\end{array}$ & $\begin{array}{c}8 \\
32\end{array}$ & $\begin{array}{l}20.0 \\
80.0\end{array}$ & $X^{2}=3.93$ & $0.047^{*}$ \\
\hline Weight [kg] & $\begin{array}{l}<3^{\text {rd }} \text { percentile } \\
>95 \text { percentile }\end{array}$ & $\begin{array}{l}22 \\
26\end{array}$ & $\begin{array}{l}45.8 \\
54.2\end{array}$ & $\begin{array}{c}7 \\
33\end{array}$ & $\begin{array}{l}17.5 \\
82.5\end{array}$ & $X^{2}=7.92$ & $0.0048^{*}$ \\
\hline Pulse [beat/min] & $\begin{array}{l}\text { Range } \\
\text { Mean } \pm S D\end{array}$ & \multicolumn{2}{|c|}{$\begin{array}{c}87-125 \\
106.42 \pm 11.04\end{array}$} & \multicolumn{2}{|c|}{$\begin{array}{c}80-112 \\
96.68 \pm 10.37\end{array}$} & $t=5.65$ & $0.001^{*}$ \\
\hline
\end{tabular}

$\mathrm{X}^{2}=$ Chi square test; $\mathrm{t}=\mathrm{t}$-test; $\mathrm{p}$ is significant if $\leq 0.05 ;{ }^{*}$ Significant at level 0.05 .

Table [2]: Comparison between the two studied groups regarding serum glucose, serum insulin level, serum iron, serum ferritin level, and liver function test.

\begin{tabular}{|c|c|c|c|c|c|}
\hline & \multirow{2}{*}{$\begin{array}{c}\text { Patients group } \\
n=48\end{array}$} & \multirow{2}{*}{$\begin{array}{c}\text { Control group } \\
n=40\end{array}$} & \multicolumn{2}{|c|}{ Test } \\
\hline & & & & $t$ & $\mathbf{P}$ \\
\hline Serum glucose [mg/dl] & $\begin{array}{c}\text { Range } \\
\text { Mean } \pm \text { S.D. }\end{array}$ & $\begin{array}{c}70-123 \\
87.42 \pm 12.78\end{array}$ & $\begin{array}{c}72-120 \\
89.58 \pm 11.26\end{array}$ & 0.89 & 0.204 \\
\hline Serum insulin & $\begin{array}{c}\text { Range } \\
\text { Mean } \pm \text { S.D. }\end{array}$ & $\begin{array}{c}5.5-90 \\
13.70 \pm 13.13\end{array}$ & $\begin{array}{c}3.5-13.3 \\
8.15 \pm 2.49\end{array}$ & 3.33 & $0.005^{*}$ \\
\hline Serum iron & $\begin{array}{c}\text { Range } \\
\text { Mean } \pm \text { S.D. }\end{array}$ & $\begin{array}{c}105-442 \\
262.15 \pm 75.48\end{array}$ & $\begin{array}{c}15-65 \\
36.15 \pm 15.16\end{array}$ & 12.5 & $0.0001^{*}$ \\
\hline Serum ferritin & $\begin{array}{c}\text { Range } \\
\text { Mean } \pm \text { S.D. }\end{array}$ & $\begin{array}{c}1344-4276 \\
2626.79 \pm 690.17 \\
\end{array}$ & $\begin{array}{c}10-122 \\
25.93 \pm 18.24\end{array}$ & 11.23 & $0.0001^{*}$ \\
\hline SGPT [IU/L] & $\begin{array}{c}\text { Range } \\
\text { Mean } \pm \text { S.D. }\end{array}$ & $\begin{array}{c}7-40 \\
14.29 \pm 6.66\end{array}$ & $\begin{array}{c}7-32 \\
15.05 \pm 5.40\end{array}$ & 0.98 & 0.282 \\
\hline SGOT [IU/L] & $\begin{array}{c}\text { Range } \\
\text { Mean } \pm S . D .\end{array}$ & $\begin{array}{c}14-65 \\
26.44 \pm 8.95\end{array}$ & $\begin{array}{c}10-31 \\
18.40 \pm 4.87\end{array}$ & 3.65 & $0.011^{*}$ \\
\hline
\end{tabular}

\footnotetext{
* Significant at level 0.05 ; $t=t-t e s t ; ~ p$ is significant if $\leq 0.05$
} 

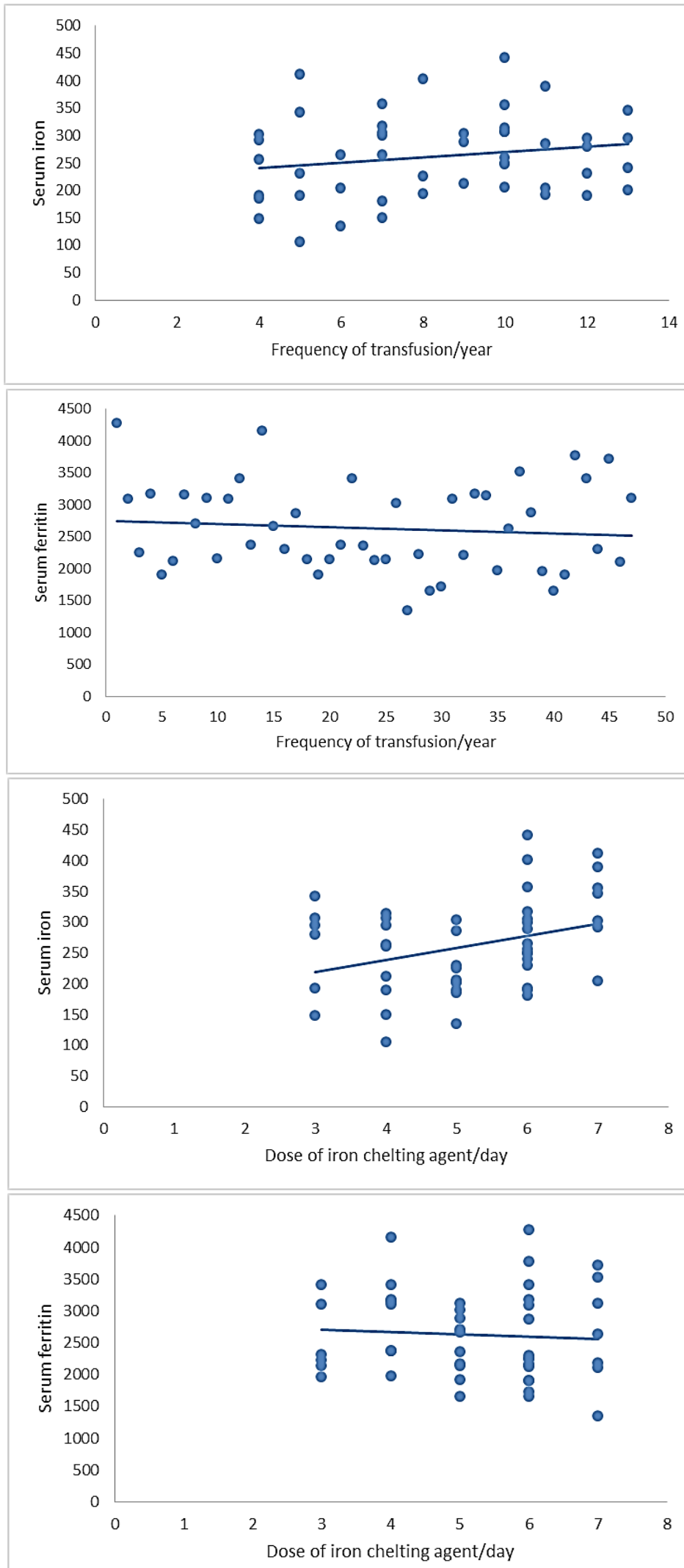

Figure [1]: Correlation between serum iron and serum ferritin in relation to age, age of onset, frequency of transfusion/year, and iron-chelating agent/day. 


\section{DISCUSSION}

Thalassemias are a heterogeneous group of genetic disorders resulting from defects in genes producing a or $\beta$ globin chains. Frequent blood transfusions have increased life expectancy and improved the quality of life for patients with TM, but it causes progressive iron overload, which is a major clinical complication of the treatment. Some evidence shows that oxidative stress [caused by iron accumulation] is the most important factor in the pathogenesis of clinical complications of the disease. A wide range of literature has documented multiple organ dysfunction, among which the heart, liver, and endocrine systems are the most common organs affected[14].

Glucose intolerance is a common consequence of transfusion therapy in patients with $\mathrm{TM}$, but the relative contribution of pancreatic damage and insulin resistance to glucose intolerance is unclear. The exact mechanism of iron-induced diabetes is unclear, but it most likely occurs through these three mechanisms: [1] insulin deficiency, [2] insulin resistance, and [3] hepatic dysfunction. Although numerous studies have been performed on endocrine and liver complications in thalassemia, the number of published studies about Iranian patients is significantly small[15].

The anthropometric measurements values in our results showed that the height and weight percentile was significantly lower in cases more in comparison with controls.

In the study carried out by Fahim et al.[13], they study the growth parameters in children with thalassemia in Upper Egypt. They carried the study on two groups cases and control; they found that the mean body mass and tallness of the cases [[15 $\pm 8.8 \mathrm{~kg}][96 \pm 86 \mathrm{~cm}]]$ were lower significantly in comparison with the control group [[26 $\pm 17 \mathrm{~kg}]$ and $[119 \pm 25 \mathrm{~cm}]] ; P<-2]$, in comparison to $2 \%$ of controls $[P<0.001]$. $47 \%$ of the cases were underweight; $38 \%$ were medium [weight z-score <-2] and $9 \%$ were extreme [weight $z$ - score $<-3$ ] [13].

Hashemi et al. concluded under-weight in $45.71 \%$ and low BMI in $18.6 \%$ of their cases with BTM[15]. Shamshirsaz et al. concluded a low mass of the body compared with the control group [17], and
Chekir et al. stated mass lateness in their cases by $14.28 \%\left[{ }^{[18]}\right.$. But few studies; demanded that the mean body mass and BMI of their thalassemic cases were in the ordinary interval and insignificant difference than their control group. Growing problems is mutual in cases of thalassemia[19].

The consequences of our work displayed that the mean pulse in cases was $106.42 \pm 11.04$ while in the control group was $96.68 \pm 10.37$; there was a significant increase in patients in comparison with the controls $[p<0.05]$. The temperature in the two groups was around $37^{\circ} \mathrm{C}$, and no significant change among the studied groups was detected concerning temperature $[p>0.05]$.

In approval to our consequences Elsehaimy et al.[20], study the evaluation of pulmonary functions in pediatric patients with beta-thalassemia major; they found that the heart rate and respiratory rate was significantly higher in cases more than the control group $[p<0.01]^{[20] \text {. }}$

For the current study, the mean serum glucose in patients was $87.4 \pm 12.78$, while in the control group was $89.5 \pm 11.26$, with no significant change among groups of the study as regards the serum insulin, it was $13.7 \pm 13.13$ in the patients' group, while in the control group was $8.15 \pm 2.49$, with the significant increase in cases more in comparison with the controls $[p<0.05]$.

In agreement with our results, Ghergherehchi et al.[21], study the Insulin Opposition and $\beta$ - Cell Role in cases of $\beta$-Thalassemia major; they found that there was a significant elevation in serum insulin in the patients' group more than the control group [21].

In contrast to our results, Shams et al.[22], study the assessment of serum insulin, lipid profile, glucose, and liver function in $\beta$-Thalassemia major cases and its relationship with iron excess. They found that the serum glucose amount was significantly higher for the cases in comparison within the control group $[P=0.000]$, while the fasting serum insulin exhibited no significant change among the serum insulin level of the studied groups $[P=0.215]^{22]}$.

These contradictory consequences are symptomatic of a multi-factorial procedure in the 
growth of DM in $\beta$-TM. It is probable that a raised iron level and ferritin lead to toxicity with iron in the liver and pancreas and insulin dysregulation because of hepatic and pancreatic dysfunction, which is more possible the reason for reduced glucose metabolism. In preceding investigations, abnormal glucose metabolism was described along with reduced insulin secretion and insulin opposition in hemochromatosis and $\beta$-Thalassemia cases experiencing chelation treatment[23,24].

Iron excess is suggested as the possible way for these results that may lead to opposition by itself or its correlated hepatic dysfunction[25].

It was proposed that numerous ways such as insulin shortage, insulin opposition, hepatic dysfunction, genetic features, and auto-immunity in the deficiency of anti-islet cell anti-bodies might exchange iron-induced abnormal glucose metabolism [26].

But it must be observed that insulin secretion and insulin sensitivity are commonly correlated. $\beta$ Thalassemia major cases have a mixture of disease spectrum with insulin opposition [produced by a mixture of oxidative stress to vascular endothelia and liver harm] and $\beta$-cell dysfunction [produced directly by iron-toxicity to the islet cells]. These variations drive insulin secretion in a reverse way; thus, it is not shocking that fasting insulin level is ordinary[27].

Issues like as a family history of DM and hepatitis $C$ are proposed risks for the growth of DM in these cases, we excepted patients with similar conditions, and so we may assume that the detected outcomes are frequently linked to iron excess. But, by means of multivariate reversion analyses, we concluded that no factor that may expect anomalous OGTT consequences and detected that only ALT might expect DM[28].

In our results, the mean serum iron in patients was $262.1 \pm 75.48$, while in control was $36.15 \pm$ 15.16 , the serum ferritin in patients was $2626.79 \pm$ 690.17 , while in control was $25.93 \pm 18.24$, there was a highly significant increase in serum iron and serum ferritin in patients more than the control. In agreement with our study, Koreti et al. study the Serum ferritin levels in $\beta$-Thalassemia, major children, they found that Serum ferritin level was detected to be raised in all the patients of $\beta$ thalassemia major with a range from 1050 to 5029 $\mu \mathrm{g} / \mathrm{l}$ with a mean value of $3879 \mu \mathrm{g} / \mathrm{l}$. The cases are aging at diagnosis time ranging from 4 months to 16 months with a mean of 10 months. The period among periodic blood transfusions changed amid one weak to four weeks in various cases [29].

In this study, the liver function test showed that the SGPT in the patients and control was matched without significant difference, while the SGOT show a slightly significant increase in patients more than the control $[p<0.05]$. There was no significant correlation between liver enzymes and either serum iron or serum ferritin $[P>0.05]$. In accordance with our results, Salama et al. study the Liver Enzymes in Children with $\beta$-Thalassemia Major: Relationship with Iron Excess and Viral Hepatitis. The investigation involved 80 cases with $\beta$-thalassemia major; the ages ranging from 4-18 years, they concluded that the mean level of ALT and GGT in cases with high ferritin level $[>320 \mu \mathrm{g} / l]$ are high significantly in comparison with those with the level of ferritin $[<320 \mu \mathrm{g} / \mathrm{l}], \quad[\mathrm{p}=0.04$ and 0.05 respectively] ${ }^{[30]}$.

In our results, the correlation between serum iron and serum ferritin in relation to age, age of onset, frequency of transfusion/year, and the dose of iron cheating agent/day indicated significant positive association existed among both serum iron in relation to the frequency of transfusion/year and the dose of iron-chelating agent/day, and negative correlation between serum ferritin and both to the frequency of transfusion/year and the dose of ironchelating agent/day. While the age, age of onset, and duration of the disease show insignificant relation with both serum iron and ferritin.

In agreement with our study, Fathi et al.[31], study the effect of treatment with deferoxamine on the serum iron and ferritin; they found a significant positive correlation existing among both serum iron in relation to the frequency of transfusion/year and a dose of iron-chelating agent/day, and negative association among serum ferritin and both to the frequency of transfusion/year and the dose of ironchelating agent/day[31]. Davis et al. in a work presented that administration of 24-hour intra- 
venous deferoxamine with a suitable dose via the catheter guides to progressing serum ferritin disorder and significantly decreases half the primary values. Wali et al. presented that one-year afterward usage of high-dose intravenous Deferoxamine [200-240 mg per $\mathrm{kg}$ per day] with subcutaneous infusion through 3 - days [every 10 hours], the serum ferritin, and urinary defecation of iron [as a marker of iron excess] were significantly reduced[32].

In conclusion, the children with $\beta$-TM have a high glycemic disorders incidence, maybe because of insulin resistance secondary to excess in iron load. Deferiprone containing chelation treatment might have protecting consequence. It is recommended to follow up the $\beta$-thalassemia Major patients clinically and laboratory, especially the liver function test, serum insulin, and glucose level. The level of serum iron and ferritin must be evaluated regularly for the $\beta$-thalassemia patients. It was recommended to study the relation between serum insulin, glucose, and liver function in $\beta$-thalassemia Major on a large number of cases and for a longer period of follow up

Financial and Non-financial Relationships and Activities of Interest

None

\section{REFERENCES}

1-Galanello R, Origa R. Beta-Thalassemia Orphanet J Rare 2010; 5:11. doi: 10.1186/1750-1172-5-11.

2-Modell B, Darlison M. Global epidemiology of hemoglobin disorders and derived service indicators. Bull World Health Organ. 2008; 86[6]: 480-7. doi: 10.2471/blt.06.036673.

3-Hassan T, Badr M, El Safy U, Hesham M, Sherief L, Zakaria M. $\beta$-Thalassemia: genotypes and phenotypes. In: Epidemiology of communicable and non-communicable diseases-attributes of lifestyle and Nature on Humankind, 2016; pp 113126. doi: $10.5772 / 64644$

4- Nienhuis AW, Nathan DG. Pathophysiology and Clinical Manifestations of the $\beta$-Thalassemias. Cold Spring Harb Perspect Med. 2012; 2(12): a011726. doi: 10.1101/cshperspect.a011726.

5- Greer JP, Arber DA, Glader B, List AF, Means RT.
Wintrobe's clinical hematology, Lippincott Williams \& Wilkins. Philadelphia, PA. 2013; doi: 10.1148/ radiol.14144027.

6-McCance KL, Huether SE. Pathophysiology: The Biologic Basis for Disease in Adults and Children, St. Louis, Mo. 2014; 28 [48]; 30 doi:10.7748/ ns.28.48.30.s36

7- Barton J C, Edwards CQ, Phatak PD, Britton RS, Bacon BR. Handbook of iron overload disorders. Cambridge University Press. 2010; 28 -33.doi. 10. 1017/cbo9780511777035.005

8- De Sanctis V, Soliman A, Yassin M. Iron overload and glucose metabolism in subjects with $\beta$ thalassemia major: An overview. Curr Diabetes Rev. 2013; 9[4]:332-41. doi: 10.2174/15733998 11309040005.

9- Fernandez-Real JM, Manco M. "Effects of iron overload on chronic metabolic diseases. Lancet Diabetes Endocrinol. 2014; 2[6]:513-26. doi: 10. 1016/ S2213-8587[13]70174-8.

10- Lecube A, Hernandez C, Simo R. Glucose abnormalities in non-alcoholic fatty liver disease and chronic hepatitis $C$ virus infection: the role of iron overload. Diabetes Metab Res Rev. 2009; 25 [5]: 403-10. doi: 10.1002/ dmrr.972.

11- Kaufman FR. Role of the continuous glucose monitoring system in pediatric patients. Diabetes Technol Ther. 2000; 2 Suppl 1:S49-52. doi: 10. 1089/15209150050214122.

12- World Health Organization. Life in the $21^{\text {st }}$ century: A vision for all. Geneva. 2008; 316 - 60. doi.org/10. 4337/9781783479283.00018

13-World Health Organization. Introduction of hepatitis $B$ vaccine into childhood immunization services: Management guidelines, including information for health workers and parents [No. WHO/V\&B/01.31]. World Health Organization. 2001.

14- Fahim FM, Saad K, Askar EA, Eldin EN, Thabet AF. Growth Parameters and Vitamin D status in Children with Thalassemia Major in Upper Egypt. Int J Hematol Oncol Stem Cell Res. 2013; 7 [4]:10-4. PMID: 24505537

15- Hashemi A, Ghilian R, Golestan M, Akhavan GM, Zare Z, Dehghani MA. The study of growth in thalassemic patients and its correlation with serum ferritin level. Iran J Ped Hematol Oncol. 2011; 1[4]. doi. 10.3109/08880010903530915

16-Lafferty JD, Barth DS, Sheridan BL, McFarlane 
AG, Halchuk LM, Crowther MA. Prevalence of thalassemia in patients with microcytosis referred for hemoglobinopathy investigation in Ontario: a prospective cohort study. Am J Clin Pathol. 2007; 127[2]:192-196. doi: 10.1309/P6HM33F4D05T 30YM

17- Shamshirsaz AA, Bekheirnia MR, Kamgar M, Pourzahedgilani N, Bouzari N, Habibzadeh M, Larijani, B. Metabolic and endocrinologic complications in beta-thalassemia major: a multicenter study in Tehran. BMC Endocr Disord. 2003; 12; 3[1]:4. doi: 10.1186/1472-6823-3-4.

18-Kassab-Chekir A, Laradi S, Ferchichi S, Khelil AH, Feki M, Amri F, Miled A. Oxidant, antioxidant status and metabolic data in patients with betathalassemia. Clin Chim Acta. 2003; 338[1-2]:79-86. doi: 10.1016/j. cccn. 2003.07.010

19- Hamed EA, El-Melegy NT: Renal functions in pediatric patients with beta-thalassemia major: relation to chelation therapy: original prospective study. Ital J Pediatr. 2010; 25;36:39. doi: 10.1186/1824-7288-36-39.

20- Elsehaimy LA. Zineldin MA. Khalil WA. Evaluation of pulmonary functions in pediatric patients with beta-thalassemia major. Al-Azhar Assiut Medical Journal, 2019; 17[3], 264. doi: 10.4103/16871693.278404

21- Ghergherehchi R. Habibzadeh A. Insulin Resistance and $b$ Cell Function in Patients with $b$ Thalassemia Major. Hemoglobin 2015; 39[1]: 6973. doi: $10.3109 / 03630269.2014 .999081$.

22-Shams S, Ashtiani $H$, Monajemzadeh $M$, Koochakzadeh L, Irani H, Jafari F, Mohseni A. Evaluation of Serum Insulin, Glucose, Lipid Profile, and Liver Function in $\beta$-Thalassemia Major Patients and Their Correlation with Iron Overload, Lab Med. 2010; 41[8]: 486-9. doi:10. 1309//ms0eoouzsii2bne

23- Tangvarasittichai S, Pimanprom A, Choowet A, Tangvarasittichai $\boldsymbol{O}$. Association of iron overload and oxidative stress with insulin resistance in transfusion-dependent $b$-thalassemia major and $b$ thalassemia/Hb E patients. Clin Lab. 2013; 59[78]:861-8. doi: 10.7754/clin.lab.2012.120906.

24- Kurtoglu AU, Kurtoglu E, Temizkan AK. Effect of iron overload on endocrinopathies in patients with b-thalassaemia major and intermedia. Endokrynol Pol. 2012; 63[4]:260-3. PMID: 22933160

25- Shah N, Mishra A, Chauhan D, Vora C. Shah NR.
Study on effectiveness of transfusion program in thalassemia major patients receiving multiple blood transfusions at a transfusion center in Western India. Asian J Transfus Sci. 2010; 4[2]: 94-8.doi: 10. 4103/0973-6247.67029.

26-Noetzli LJ, Mittelman SD, Watanabe RM, Coates TD, Wood JC. Pancreatic iron and glucose dysregulation in thalassemia major. Am J Hematol. 2012; 87[2]:155-60. doi: 10.1002/ ajh.22223. Epub 2011 Nov 24.

27- Ragab LA, Hamdy MM, Shaheen IA, Yassin RN. Blood transfusion among thalassemia patients: A single Egyptian center experience. Asian J Transfus Sci. 2013; 7[1]:33-6. doi: 10.4103/09736247.106728

28- De Assis RA, Ribeiro AA, Kay FU, Rosemberg LA, Nomura CH, Loggetto SR, Espósito BP. Pancreatic iron stores assessed by magnetic resonance imaging [MRI] in $\beta$-thalassemia patients. Eur J Radiol. 2012; 81[7]: 1465-70. doi: 10.1016/ j.ejrad.2011.03.077.

29-Koreti S, Gaur BK, Das G, Gaur A. Study of Serum ferritin levels in $\beta$-Thalassemia major children. Int $\mathrm{J}$ Pediatr Res. 2018; 5[6]:308-313. doi: 10.17511/ ijpr. 2018.106.02

30-Salama KM, Ibrahim OM, Kaddah AM, Boseila S, Ismail LA, Hamid MM. Liver Enzymes in Children with beta-Thalassemia Major: Correlation with iron overload and viral hepatitis. Open Access Maced J Med Sci. 2015; 15; 3[2]:287-92. doi: 10. 3889/ oamjms. 2015.059.

31- Fathi A, Amani F, Araghchin S, Farzaneh E. Effect of intravenous Deferoxamine concomitant use with blood transfusion on serum ferritin in thalassemia major patients. Int J Basic Clin Pharmacol. 2017; 6[2], 399-403. doi.org/10.18203/2319-2003. ijbcp 20170337

32-Wali YA, Taqi A, Deghaidi A. Study of intermittent intravenous deferrioxamine high-dose therapy in heavily iron-loaded children with beta-thalassemia major poorly compliant to subcutaneous injections. Pediatric Hematol Oncol. 2004; 21[5]:453-60. doi.10.1080/08880010490457259 


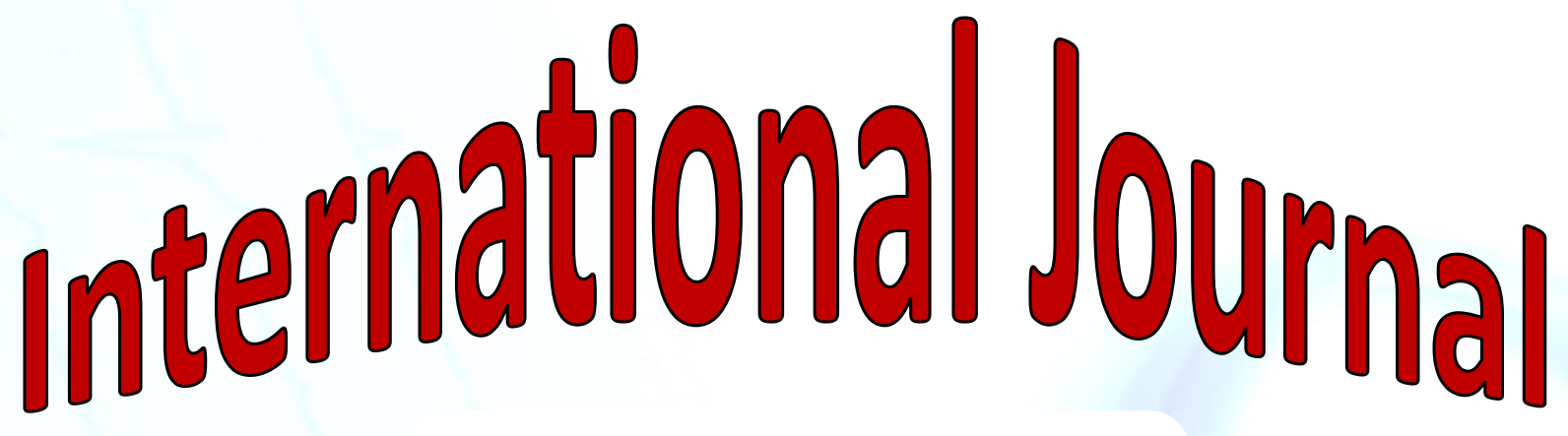

https://ijma.journals.ekb.eg/

Print ISSN: 2636-4174

Online ISSN: 2682-3780

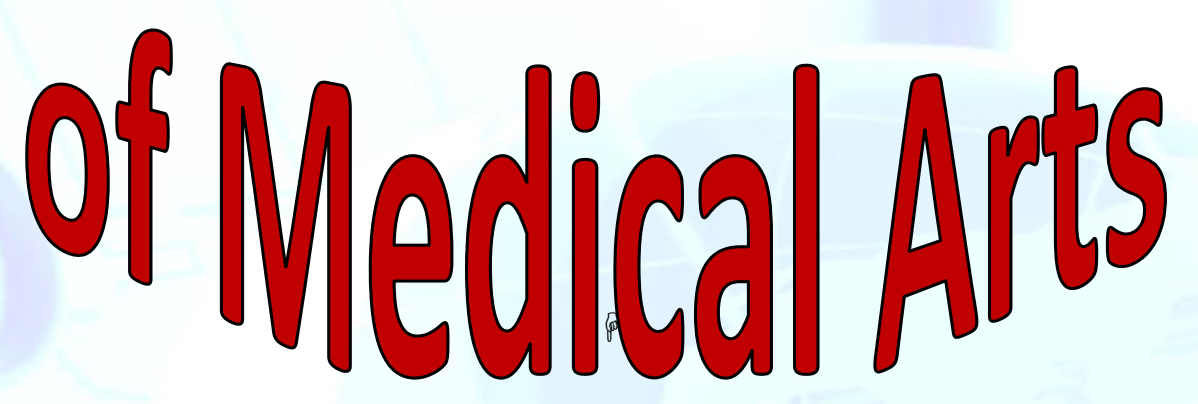

